\title{
Validation of immunoaffinity-HPLC/PDA method for microvitamin (biotin and cobalamins) analysis in marine resources and products
}

\author{
Ye-Eun Park ${ }^{1}$, Ki-Ho Nam ${ }^{2}$, Yeon-Kye $\mathrm{Kim}^{2}$, Jiyeon Chun ${ }^{1 *}$ \\ ${ }^{1}$ Department of Food Science and Technology, Sunchon National University, Suncheon 57922, Korea \\ ${ }^{2}$ Food Safety and Processing Research Division, National Institute of Fisheries Science, Busan 46083, Korea
}

\section{Immunoaffinity-HPLC/PDA를 이용한 국내 수산자원 및 제품의 미량비타민 $\mathrm{B}_{7}$ (비오틴) 및 $\mathrm{B}_{12}$ (코발라민류) 분석 및 검증}

\author{
박예은 ${ }^{1} \cdot$ 남기호 $^{2} \cdot$ 김연계 $^{2} \cdot$ 천지연 ${ }^{1 *}$ \\ ${ }^{1}$ 순천대학교 식품공학과, ${ }^{2}$ 국립수산과학원 식품위생가공과
}

\begin{abstract}
Given that Korea is surrounded by water on three sides, fishery resources are abundant and consumed nationwide. To assess the dietary intake of micronutrients, reliable analysis should be performed. However, there is no verified method for the analysis of vitamins $B_{7}$ and $B_{12}$ in fishery resources. In this study, the immunoaffinity-high performance liquied chromatography (HPLC)/photodiode array-detector (PDA) was validated and applied to analyze microvitamins $B_{7}$ (biotin) and $B_{12}$ (cobalamins) in fishery producus. The specificity of the immunoaffinity-HPLC/PDA method was good for biotin and cyanocobalamin. The analytical quantitation limits for biotin and cyanocobalamin were 0.028 and $0.014 \mu \mathrm{g} / 100 \mathrm{~g}$, respectively. The recovery of vitamins $B_{7}$ and $B_{12}$ ranged from $99.0 \%$ to $101.3 \%$, indicating a good accuracy. The repeatability (CV 3.6\%-3.8\%) and reproducibility (CV 4.9\%-6.1\%) of immunoaffinityHPLC/PDA assay for vitamins $B_{7}$ and $B_{12}$ were acceptable, indicating good precision. Vitamins $B_{7}$ (1.06 to 10.55 $\mu \mathrm{g} / 100 \mathrm{~g})$ and $B_{12}(0.36$ to $36.13 \mu \mathrm{g} / 100 \mathrm{~g})$ were detected in all fishery products $(\mathrm{n}=28)$ including 4 fish, 3 crustaceans, 3 marine algae, 3 cephalopods, 4 shellfish, 3 others and 8 products. The highest vitamin $B_{7}$ and $B_{12}$ contents were found in gazami crabs and ark shells, respectively. In conclusion, our data could be used for establishing national vitamin database on Korean fishery resources.
\end{abstract}

Key words : method validation, immunoaffinity-HPLC, biotin, vitamin $B_{12}$, marine resources

서 론

한국에서 수산자원은 동물성 단백질 공급량의 $39 \%$ 를 점 유하고 있는 중요 영양공급원 중 하나로, 우리나라는 반도의 지형적 특성에 따라 예로부터 다양한 수산물이 이용되고 있 으며(Lee와 Kim, 2003), 한국인 1인당 수산물 섭취량은 58.4 $\mathrm{kg} /$ 년으로 세계 1 위를 차지하고 있는 것으로 보고되어 있다
(Norway Seafood Commission, 2017). 국내에서는 국립수산 과학원에서 주기적으로 표준수산물 성분표를 발간하여 수산 물 및 수산식품에 대한 각종 영양성분을 제공하고 있으나, 지 금까지 발간된 표준수산물성분표(2018)에서 수용성 비타민 에 대한 데이터는 비타민 $\mathrm{B}_{1}, \mathrm{~B}_{2}, \mathrm{~B}_{3}, \mathrm{C}$ 성분만을 수록하고 있어 올바른 국민영양정책 수립을 위해서는 이 외의 수용성 비타민에 대한 데이터베이스 구축이 시급한 실정이다.

*Corresponding author. E-mail : cjyfall@gmail.com, Phone : +82-62-750-3208, Fax : +82-62-750-3250

Received 28 September 2020; Revised 20 October 2020; Accepted 20 October 2020.

Copyright (c) The Korean Society of Food Preservation.

This is an Open Access article distributed under the terms of the Creative Commons Attribution Non-Commercial License (http://creativecommons.org/licenses/by-nc/4.0) which permits unrestricted non-commercial use, distribution, and reproduction in any medium, provided the original work is properly cited. 
비타민(vitamin)은 미량필수영양소로 구분되고, 인체 내에 서 신체 기능을 조절하는 효소 또는 조효소의 구성성분으로 탄수화물, 지방, 단백질, 무기질 대사에 관여하며, 결핍 시 체 내 영양소 대사에 지장을 주게 된다. 비타민류는 인체 내에서 합성되지 않기 때문에 식품이나 보조제를 통해 필수적으로 섭취해야 하는 영양소로, 최근 건강기능식품에 대한 요구도 가 높아지면서 미량영양소 섭취 수준에 관한 관심이 증가하 고 있다(Kim 등, 2005). 특히, 비오틴(biotin, 비타민 $\mathrm{B}_{7}$ )과 코 발라민류(cobalamins, 비타민 $\mathrm{B}_{12}$ )와 같이 식품 중 낮은 함량 으로 존재하고 있는 미량비타민류는 분석 시 검출 및 정량이 어려운 분석적 한계, 국민영양정책 수립을 위한 미량성분에 대한 데이터베이스의 구축 필요성에 대한 인식 부족 등으로 인하여 그동안 국가영양성분 데이터베이스 구축 항목에서 누 락되어 왔다. 최근, 올바른 국민영양보건정책 수립을 위해 이 러한 미량비타민을 포함한 확대된 데이터베이스 구축의 필요 성이 확산되면서 미량비타민의 분석법의 유효성 검증 및 이 를 통한 다양한 자원들의 데이터베이스 구축이 시도되고 있 다(Kwak 등, 2012; Mun 등, 2017; Shin 등, 2016). 식품 중 비오틴과 코발라민류의 분석은 함량이 검출하기 어려운 낮은 수준으로 존재하기 때문에 추출 후 검출 및 정량 한계 이상으 로 농축이 필요한데, 이 과정에서 분석에 간섭을 일으키는 불 순물도 함께 농축되는 것을 막기 위해 목적하는 분석 성분을 선택적으로 농축하는 과정이 필요하다. 최근 이용되고 있는 면역친화성컬럼(immunoaffinity column)은 비오틴과 시아노 코발라민과 같은 미량 성분을 컬럼 내부의 면역친화성 겔과 특이적인 결합을 유도시키고, 기타 분석 간섭물질들을 효과 적으로 제거함으로써 목적하는 성분을 농축 및 clean-up하는 방법에 적용할 수 있어 비오틴과 코발라민류와 같은 미량비 타민 분석에 적용되고 있다(Cheon, 2019; Senyuva와 Gilbert, 2010).

비오틴은 비타민 $\mathrm{B}_{7}$ 또는 비타민 $\mathrm{H}$ 로 알려져 있는 수용성 비타민으로 $d$-biotin과 $d$-biocytin의 형태로 존재한다. 비오틴 은 자연 상태에서 유리형과 결합형으로 나뉘며, 결합형은 식 품에서는 단백질과 결합되어 있는 것으로 알려져 있다 (Lahely 등, 1999). 비오틴은 체내에서 발생하는 정상적인 세 포 기능 및 성장에 필수적인 영양소로 작용하며 주로 체내 장에서 흡수되어 이용된다(Said 등, 1990). 비오틴의 생체 주 요 반응으로는 포도당 신생 합성, 지방산 합성, 아미노산 대 사를 포함하는 여러 carboxylase의 조효소 역할을 하는데 (Pacheco-Aluarez 등, 2002; Holler 등, 2006), 결핍 시 식욕 부진, 우울증, 결막염, 탈모, 피부발진 등의 질병을 야기하지 만, 비오틴 결핍에 대해서는 거의 보고된 바가 없으며, 과다 복용에 대한 부작용도 현재까진 알려진 바가 없다(Bellows와 Moore, 2012; Zempleni와 Mock, 1998).
코발라민류는 cobalt corrinoid 중 비타민 $\mathrm{B}_{12}$ 기능을 나타 내는 코발라민류 화합물을 총칭하는데, 자연 식품에서는 다 양한 형태로 존재하고 비타민 $\mathrm{B}_{12}$ 강화식품의 경우 안정한 합성형 시아노코발라민으로 존재한다(Martens 등, 2002). 코 발라민류는 식품 중 단백질과 결합되어 있어 섭취 시 위산과 펩신에 의해 단백질 복합체와 분리된 후 위벽에 존재하는 내 인성 단백질과 결합되어 근위 회장에서 원위 회장으로 이동 되고, 이후 transcobalamin 페 겔합되어 간과 골수로 수송 된 후 라이소자임에 의해 분해된 후 체내에서 흡수된다 (Petrus 등, 2009; Swain, 1995). 코발라민류는 주로 동물성 식품과 일부 해조류와 버섯류에만 존재하며, 식물성 식품에 서는 발견되지 않기 때문에 채식주의자, 동물성 식품 섭취가 어려운 노인들, 위 절제 환자 및 흡수 장애가 있는 사람들에 게 비타민 $\mathrm{B}_{12}$ 결핍이 종종 발생하는 것으로 보고되어 있다 (Andres 등, 2004; Carmel, 2000). 결핍 시 신경학적 증상 (Healton 등, 1991), 거대적 혈모구 빈혈 등의 질병을 유발하 며, 특히 빈혈은 비타민 $\mathrm{B}_{12}$ 결핍의 가장 흔한 원인 중 하나 로 분류되고 있다(Stabler, 2013).

본 연구에는 국내에서 이용되는 다양한 수산자원의 미량비 타민 데이터베이스 확보를 위해 immunoaffinity-HPLC/PDA 분석법을 검증하고 총 7 개 군으로부터 28종의 시료에 적용하 여 수산자원별 비오틴과 코발라민류 데이터베이스 구축 및 데이터의 신뢰도를 확보하고자 하였다.

\section{재료 및 방법}

\section{시약 및 시료 준비}

비오틴과 코발라민류 분석정량을 위한 biotin 및 cyanocobalamin 표준품과 추출용매 제조에 사용한 sodium phosphate monobasic, sodium phosphate dibasic hepta-hydrate, phosphate buffer saline은 Sigma-Aldrich사(St. Louis, MO, USA), sodium acetate trihydrate와 acetic acid는 Wako사 (Osaka, Japan)에서 구입하여 사용하였다. 이외 기타 시약 및 용매는 특급 및 HPLC 급을 구입하여 사용하였다.

시료는 연근해, 내수면, 다소비 수산물 중 표준수산물성분 표 2018 분류군에 따라 어류, 패류, 두족류, 갑각류, 해조류, 기타 수산물 및 수산가공품(건조품, 염장품)으로 분류한 뒤 수산물 분류군에 따른 대표 시료를 선정하였으며, 각 시료는 비가식부를 제거한 뒤 균질하여 $-70^{\circ} \mathrm{C}$ 에서 동결 보관하며 분 석 시료로 사용하였다.

분석법 검증을 위한 표준참고물질 SRM 1549a(Whole milk powder), SRM 1849a(Infant/Adult Nutritional Formula), SRM 3290(Dry Cat Food)는 NIST사(Gaithersburg, MD, USA)에서, 분석품질관리 시료로 사용된 상업용 분유는 Namyang(imperial 
dream XO world class 3, Seoul, Korea)에서 구입하였다.

\section{비오틴 및 코발라민류 추출}

비오틴 추출 방법은 Joseph 등(2016)의 방법을 변형하여 사용하였다. 먼저, 삼각플라스크에 균질된 시료 $5 \mathrm{~g}$ 을 칭량한 뒤 $0.15 \mathrm{M}$ sodium phosphate buffer(pH 7) $50 \mathrm{~mL}$ 를 넣고, 고 압멸균기(autoclave ES-315, Tokyo, Japan)에서 $121^{\circ} \mathrm{C}$ 로 30 분 간 가열하여 추출하였다. 추출된 시료는 실온으로 냉각한 뒤 원심분리한 후 Whatman No.1(GE Healthcare, Amersham Place, UK)으로 여과하여 추출액으로 사용하였다. 코발라민 류 추출은 뚜껑이 있는 $100 \mathrm{~mL}$ 플라스크에 시료를 0.5 5.0 $\mathrm{g}$ 을 칭량한 뒤 $1 \%$ sodium cyanide $0.5 \mathrm{~mL}$ 와 $0.2 \mathrm{M}$ sodium acetate trihydrate buffer( $\mathrm{pH} 4.0) 49.5 \mathrm{~mL}$ 를 가하여 10 분간 초음파(8893-DHT, Cole-Parmer, Chicago, IL, USA) 처리 후 $100^{\circ} \mathrm{C}$ 항온수조(WB-20M, Jeio Tech CO., Daejeon, Korea) 에서 1 시간 동안 추출하였다. 추출액은 냉각 후 buffer로 50 $\mathrm{mL}$ 정용한 뒤 Whatman No.1을 이용하여 여과하였다.

\section{비오틴 및 시아노코발라민 농축 및 분석}

비오틴 분석을 위한 농축 및 정제는 immunoaffinity column(Easi-Extract Biotin, r-Biopharm, Glasgow, UK)을 사용하였다. 냉장 보관된 immunoaffinity column은 사용 전 실온 온도에 맞춘 뒤 컬럼 내부의 용액을 제거하였다. 용액 제거 후 phosphate buffer saline(PBS) $3 \mathrm{~mL}$ 를 주입하여 conditioning 후 추출액 $10 \mathrm{~mL}$ 를 loading하여 비오틴 성분을 면 역친화성 컬럼에 흡착시켰다. 잔여 불순물을 제거하기 위해 PBS buffer $3 \mathrm{~mL}$ 와 초순수증류수(deionized distilled water, DDW) $6 \mathrm{~mL}$ 를 주입하여 불순물을 제거한 뒤 실린지를 이용 해 공기를 주입하여 남아있는 수분을 제거하였다. 이후 test tube에 고정시켜 methanol $4 \mathrm{~mL}$ 를 주입하여 컬럼에 흡착되 어 있는 비오틴 성분을 용출시킨 뒤 $70^{\circ} \mathrm{C}$ 에서 질소농축기 (EYELAMG-2200, Tokyo Rikakikai Co., Tokyo, Japan)로 전량 휘발시켰다. 그 후 $\mathrm{DDW} 0.5 \mathrm{~mL}$ 를 가하여 재용해시킨 뒤 $0.45 \mu \mathrm{m}$ membrane filter(cellulose acetate, Adventec, DISMIC-13CP, Osaka, Japan)로 여과한 후 vial에 옮겨 분석 에 사용하였다.

식품 중 코발라민류는 추출 후 추출용액 중의 cyanide에 의해 시아노코발라민의 형태로 전환되게 된다. 전환된 시아 노코발라민의 정제는 immunoaffinity column(Easi-Extract Vitamin $\mathrm{B}_{12}$, R-Biopharm Rhone Ltd., Glasgow, UK)을 사 용하여 검출 및 정량 수준이 되도록 농축하였다. 먼저, 실온 에서 안정화시킨 immunoaffinity column의 내부 용액을 제 거하고, water $3 \mathrm{~mL}$ 를 주입하여 conditioning하였다. 그 후 추출액 $9 \mathrm{~mL}$ 를 주입하여 시아노코발라민 성분을 흡착시킨
뒤 잔여 불순물 제거를 위해 water $9 \mathrm{~mL}$ 를 주입하였다. 실린 지를 이용하여 남아있는 수분을 제거한 후 test tube에 고정 시켜 methanol $3 \mathrm{~mL}$ 를 주입하여 시아노코발라민 성분을 용 출시켰다. 그 후 $70^{\circ} \mathrm{C}$ 에서 질소농축기를 이용하여 전량 휘발 한 후 water $0.5 \mathrm{~mL}$ 를 가하여 재용해한 뒤 $0.45 \mu \mathrm{m}$ membrane filter로 여과하여 vial에 옮겨 분석에 사용하였다.

비오틴 및 시아노코발라민의 분리 및 정량 분석은 HPLC Agilent 1260 infinity(Agilent, Santa Clara, CA, USA) 시스 템을 이용하였다. 비오틴 분석은 컬럼 Kinetex Phenyl-Hexyl (4.6 mm×150 mm, $2.6 \mu \mathrm{m}$, Phenomenex)을 사용하였으며, UV detector(PDA, G4212B, Agilent, Santa Clara, CA, $\mathrm{USA}$ )를 이용하여 파장 $200 \mathrm{~nm}$ 에서 검출하였다. 컬럼 온도 는 $25^{\circ} \mathrm{C}$, 유속은 $0.6 \mathrm{~mL} / \mathrm{min}$, 주입량은 $100 \mu \mathrm{L}$ 조건으로 분 석하였다. HPLC 이동상은 (A)- $0.1 \%$ phosphoric acid, (B)$100 \%$ acetonitrile, (C)-80\% acetonitrile 용매 비율을 A:B:C= $90: 10: 0(\mathrm{v} / \mathrm{v} / \mathrm{v})$ 으로 초기 18 분 동안 유지한 다음 18.5 분까지 $\mathrm{C}$ 용매가 $100 \%$ 가 되도록 한 후 24 분까지 유지하였으며 이후 24.5분에 A:B:C의 비율이 다시 90:10:0(v/v/v)이 되도록 하 고 이를 27 분까지 유지하는 조건으로 분석하였다. 시아노코 발라민의 분석은 $\mathrm{C}_{18} \mathrm{ACE} 3 \mathrm{AQ}(3 \mathrm{~mm} \times 150 \mathrm{~mm}, \mathrm{ACE}$, Aberdeen, Scotland, UK) 컬럼을 사용하였으며, UV detector (PDA, G4212B, Agilent)를 사용하여 $361 \mathrm{~nm}$ 에서 검출하였 다. 컬럼 온도는 $35^{\circ} \mathrm{C}$, 유속은 $0.25 \mathrm{~mL} / \mathrm{min}$, 주입량은 100 $\mu \mathrm{L}$ 이었다. 시아노코발라민의 분리를 위한 HPLC 이동상은 (A)-water와 (B)-acetonitrile을 사용하였으며, 0 분에서 A 용 매 $100 \%$ 로 시작하여 11 분에서 $\mathrm{A}$ 와 $\mathrm{B}$ 가 각각 $85 \%$ 와 $15 \%$ 가 되도록 하고, 19 분에 각각 $75 \%$ 와 $25 \%, 20$ 분에 각각 $90 \%$ 와 $10 \%, 26$ 분에 $\mathrm{A}$ 용매가 $100 \%$ 가 되도록 한 다음 35 분까지 계 속 유지하는 조건으로 분석하였다.

\section{분석법 검증(특이성, 검출/정량한계, 직선성, 정확성, 정밀성)}

분석법 검증은 국제적인 분석 검증 방법을 제시하고 있는 $\mathrm{AOAC}(2002)$ 와 $\mathrm{ICH}(2005)$ 의 검증 가이드라인에 따라 수행 하였다. 각 성분의 특이성(specificity)은 표준용액과 꽃게, $\mathrm{SRM} 1849 \mathrm{a}$ 를 PDA 검출기를 이용하여 200-600 nm에서 흡 광도를 측정하여 표준용액과 시료에 대한 분석 성분의 PDA spectrum을 비교하였다. 비오틴과 시아노코발라민의 검출한 계(limit of detection, LOD)와 정량한계(limit of quantification, LOQ)는 공시험(blank test) 시료를 분석한 후 $\mathrm{S} / \mathrm{N}$ 평 균값에 표준편차를 각각 3.3 과 10 으로 곱한 값을 더하여 산 출하였다. 추출액 중의 분석 성분의 농도에 따른 분석법의 정 량적 반응에 대한 직선성(linearity)은 각 표준용액을 농도별 로 제조하여 HPLC 분석 크로마토그램에서의 해당하는 성분 의 피크(peak)의 면적(area)을 y축, 추출액 중 분석성분의 농 
도(concentration)를 x축으로 검량선을 작성하였으며, 이들의 상관관계를 분석하여 분석법의 직선성을 평가하였다. 분석법 의 정확성(accuracy)은 표준참고물질인 SRM $1549 \mathrm{a}, \mathrm{SRM}$ $1849 \mathrm{a}, \mathrm{SRM} 3290$ 을 이용하여 비오틴과 코발라민류의 함량 을 분석한 뒤 $\mathrm{SRM}$ 을 제조한 NIST의 참고값(referencce value)과 분석법을 적용해서 얻은 실측값을 비교하여 회수율 로 나타냈다. 정밀성(precision)은 상업용 분유를 품질관리시 료로 사용하였으며, 하루 5반복 실험하여 repeatability(intra day, $\mathrm{RSD}_{\mathrm{r}}$ ), 5 일간 실험하여 reproducibility(inter day, $\mathrm{RSD}_{\mathrm{R}}$ ) 로 나타내었다.

\section{분석품질관리}

분석품질관리는 $\mathrm{AOAC}(2002)$ 가이드라인에 따라 품질관 리도표(quality control chart, QC chart)를 이용하여 관리하였 다. 품질관리시료(상업용 분유)를 반복 분석한 뒤 표준편차가 $5 \%$ 이내로 들어가는 값 10 개를 선택하여 이들의 평균값을 $\mathrm{QC}$ chart의 기준값으로 설정하였다. 관리상한선 및 관리하한 선(upper and lower control line, UCL and LCL)은 평균 $\pm(2 \times$ 표준편차), 조치상한선 및 조치하한선(upper and lower action line, $\mathrm{UAL}$ and $\mathrm{LAL})$ 은 평균 $\pm(3 \times$ 표준편차)로 설정하였다. 시 료를 분석하는 전 기간 동안 시료 분석 시마다 $\mathrm{QC}$ 시료를 분석하고, 이를 $\mathrm{QC}$ chart에 기록하여 관리선 수준하에 분석 이 진행되고 있는지 확인하였으며, 분석값이 관리 범위를 벗 어나는 경우에 분석된 검체 분석값은 사용하지 않고 실험 환 경 및 조건을 점검하여 분석이 관리 범위 내에 들어오는 것을
확인한 후 검체 분석을 진행하였다.

\section{결과 및 고찰}

\section{비오틴 및 코발라민류 분석법 검증}

비오틴 및 코발라민류의 표준품(biotin, cyanocobalamin) 과 시료(꽃게, SRM 1849a)를 HPLC-PDA로 분석한 크로마 토그램은 Fig. 1과 같다. 표준용액과 꽃게의 HPLC 크로마토 그램 비오틴 peak의 retention time은 21.5분으로 일치하였으 며, PDA spectrum도 일치하는 것을 확인할 수 있었다. 또한, 코발라민류 표준용액(cyanocobalamin)과 SRM 1849a을 분 석한 HPLC 크로마토그램(Fig. 1D, E)에서 시아노코발라민 peak는 모두 30.2분에서 검출되었고, 200-600 nm 범위에서 수집된 PDA spectrum 모두 일치하는 패턴을 보이는 것을 확 인하였다.

비오틴 및 시아노코발라민의 $\mathrm{LOD}, \mathrm{LOQ}$ 및 직선성 검증결 과는 Table 1 과 같다. 비오틴의 $\mathrm{LOD}$ 와 LOQ는 각각 0.011 $\mu \mathrm{g} / 100 \mathrm{~g}$ 와 $0.028 \mu \mathrm{g} / 100 \mathrm{~g}$ 이었다. Shin 등(2016)의 LC-MS/MS 분석법에 의한 비오틴의 LOD $0.10 \mathrm{ng} / \mathrm{mL}$ 와 LOQ $0.31 \mathrm{ng} / \mathrm{mL}$, Huh 등(2011)의 HPLC-UV 분석법에 의 한 비오틴 분석 LOD $22.5 \mathrm{ppm}$ 과 LOQ $68.3 \mathrm{ppm}$ 에 비하여 본 연구에서 적용한 immuoaffinity-HPLC/PDA 분석 LOD 및 LOQ가 보다 낮아 분석법의 민감도(sensitivity)가 높은 것 으로 보여진다. 한편, 분석법의 직선성은 표준용액을 여러 수 준의 농도로 제조하여 분석한 뒤 분석성분의 농도와 $\mathrm{HPLC}$
(A)

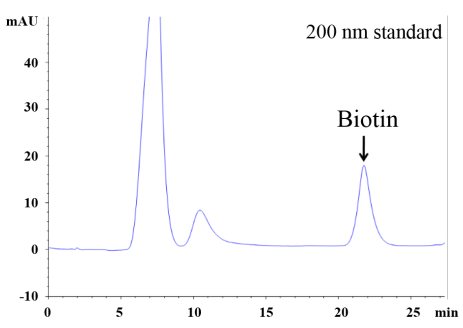

(D)

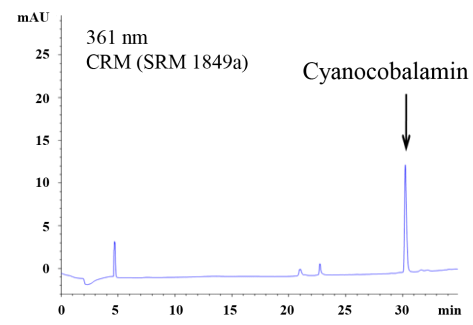

(B)

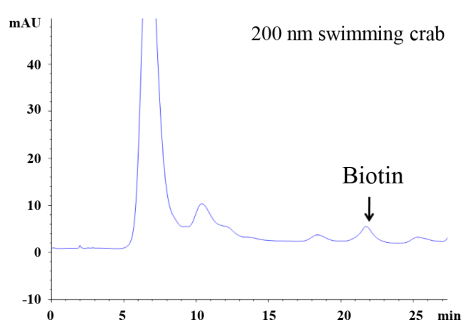

(E)

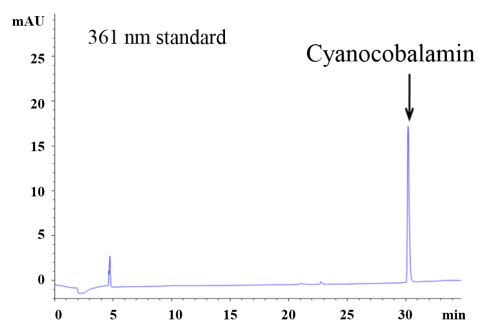

(C)

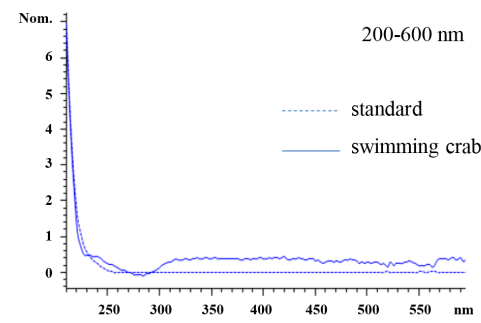

(F)

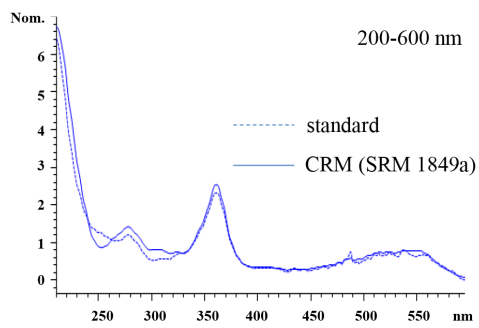

Fig. 1. HPLC chromatograms at $200 \mathrm{~nm}$ for biotin and $361 \mathrm{~nm}$ for cyanocobalamin (A, B, D, and E) and PDA spectrums (C and F) at 200-600 $\mathrm{nm}$ of standards ( $A$ and $D)$ and samples (B and E) for biotin and cyanocobalamin analyses. (A)-(C) and (D)-(F) are for biotin and cyanocobalamin analyses, respectively. 
Table 1. LOD, LOQ and linearity of immunoaffinity-HPLC/PDA for vitamin $B_{7}$ and $B_{12}$ analyses

\begin{tabular}{lcccc}
\hline Analytes & $\begin{array}{c}\mathrm{LOD}^{1)} \\
(\mu \mathrm{g} / 100 \mathrm{~g})\end{array}$ & $\begin{array}{c}\left.\mathrm{LOQ}^{2}\right) \\
(\mu \mathrm{g} / 100 \mathrm{~g})\end{array}$ & $\begin{array}{c}\text { Linearity equation } \\
(\mathrm{y}=\mathrm{Ax}+\mathrm{B})\end{array}$ & $\begin{array}{c}\text { Correlation coefficient } \\
\left(\mathrm{R}^{2}\right)\end{array}$ \\
\hline Vitamin $\mathrm{B}_{7}$ (biotin) & 0.011 & 0.028 & $\mathrm{y}=1119.7 \mathrm{x}+0.6929$ & 0.9998 \\
Vitamin $\mathrm{B}_{12}$ (cyanocobalmin) & 0.005 & 0.014 & $\mathrm{y}=2092.7 \mathrm{x}-10.461$ & 0.9996 \\
\hline
\end{tabular}

${ }^{1)} \mathrm{LOD}$, limit of detection.

${ }^{2)} \mathrm{LOQ}$, limit of quantification.

에서의 검출 반응 면적과의 관계를 분석한 결과, $\mathrm{y}=$ $1,119.7 x+0.6929$ 의 관계식과 상관계수 $\mathrm{R}^{2}=0.9998$ 을 얻어 직 선성이 높음을 확인하였다. 한편, 시아노코발라민의 LOD 및 $\mathrm{LOQ}$ 는 각각 $0.005 \mu \mathrm{g} / 100 \mathrm{~g}$ 과 $0.014 \mu \mathrm{g} / 100 \mathrm{~g}$ 으로 나타났다 (Table 1). Mun 등(2017)의 보고에서는 HPLC-DAD 분석법 의 $\mathrm{LOD}$ 및 $\mathrm{LOQ}$ 는 각각 $0.01 \mu \mathrm{g} / 100 \mathrm{~g}$ 과 $0.03 \mu \mathrm{g} / 100 \mathrm{~g}$ 이었 으며, Jeong 등(2018)은 HPLC-PDA 분석법에 의한 LOD 및 $\mathrm{LOQ}$ 는 각각 $0.012 \mu \mathrm{g} / 100 \mathrm{~g}$ 과 $0.032 \mu \mathrm{g} / 100 \mathrm{~g}$ 이었다고 보고 하였다. 이에 비하여 본 연구의 시아노코발라민 LOD 및 $\mathrm{LOQ}$ 값이 낮아 분석법의 민감도가 높은 것으로 보여진다, 본 연구에서의 시아노코발라민 분석법은 성분의 농도 수준과 검량 반응도의 관계가 $\mathrm{y}=2,092.7 \mathrm{x}-10.461$ 의 직선성을 보였으 며 상관계수 $\mathrm{R}^{2}=0.9996$ 의 값을 나타내 높은 직선성을 나타냄 을 확인할 수 있었다.
비오틴과 코발라민류 분석법의 정확성 검증을 위해 표준 관리물질(SRM 1549a, SRM 1849a, SRM 3290)을 분석한 결 과는 Table 2 와 같다. 비오틴의 표준관리물질 분석 결과 $15.226 \mu \mathrm{g} / 100 \mathrm{~g}(\mathrm{SRM}$ 1549a), $140.605 \mu \mathrm{g} / 100 \mathrm{~g}(\mathrm{SRM}$ 3290)의 값을 나타내었다. NIST에서 제시하는 인증값은 각 각 $15.200 \mu \mathrm{g} / 100 \mathrm{~g}(\mathrm{SRM} 1549 \mathrm{a}), 142.00 \mu \mathrm{g} / 100 \mathrm{~g}(\mathrm{SRM}$ $3290)$ 으로 $100.2 \%, 99.0 \%$ 의 회수율을 나타내었다. 코발라민 류의 표준관리물질 분석 결과 $4.848 \mu \mathrm{g} / 100 \mathrm{~g}(\mathrm{SRM} 1849 \mathrm{a})$, $9.628 \mu \mathrm{g} / 100 \mathrm{~g}(\mathrm{SRM}$ 3290)의 값을 나타내었으며 각각 $100.6 \%, 101.3 \%$ 의 회수율을 나타내었다. $\mathrm{AOAC}$ 가이드라인 에서 제시하는 회수율 수용범위는 75-120\%(1 $\mu \mathrm{g} / 100 \mathrm{~g}$ 기 준)를 나타내며, 두 성분 모두 범위에 충족하는 회수율을 보 여 우수한 정확성을 확인하였다.

정밀성 평가는 반복성(repeatability)과 재현성(reproduci-

Table 2. Accuracy of immunoaffinity-HPLC/PDA for vitamin $B_{7}$ and $B_{12}$ analyses

\begin{tabular}{lcccc}
\hline Analytes & Samples $^{1)}$ & Reference value $(\mu \mathrm{g} / 100 \mathrm{~g})^{2)}$ & ${\text { Analysis values }(\mu \mathrm{g} / 100 \mathrm{~g})^{3)}}^{\text {Recovery }(\%)^{4)}}$ \\
\hline \multirow{2}{*}{ Vitamin B (biotin) } & SRM 1549a & $15.20 \pm 1.60$ & $15.23 \pm 0.89$ & 100.2 \\
& SRM 3290 & $142.00 \pm 23.00$ & $140.61 \pm 2.63$ & 99.0 \\
\hline \multirow{2}{*}{ Vitamin B 12 (cyanocobalmin) } & SRM 1849a & $4.82 \pm 0.85$ & $4.85 \pm 0.07$ & 100.6 \\
& SRM 3290 & $9.50 \pm 2.50$ & $9.63 \pm 0.17$ & 101.3 \\
\hline
\end{tabular}

${ }^{1)}$ SRM (standard reference material) 1549a, 1849a and 3290 indicate whole milk powder, infant/adult nutritional formula and dry cat food, respectively.

${ }^{2)}$ The reference values for the contents of corresponding analytes in SRMs provided by NIST.

${ }^{3)}$ The analytical value obtained in this study.

${ }^{4)}$ Recovery $(\%)=100 \times($ analysis value/reference value $)$.

Table 3. Precision of immunoaffinity-HPLC/PDA for vitamin $B_{7}$ and $B_{12}$ analyses

\begin{tabular}{|c|c|c|c|c|}
\hline \multirow{2}{*}{ Analytes } & \multicolumn{2}{|c|}{ Repeatability $^{1)}$} & \multicolumn{2}{|c|}{ Reproducibility $\left.{ }^{2}\right)$} \\
\hline & Mean $\pm \mathrm{SD}^{3)}(\mu \mathrm{g} / 100 \mathrm{~g})$ & $\mathrm{CV}^{4)}(\%)$ & Mean \pm SD $(\mu \mathrm{g} / 100 \mathrm{~g})$ & $\mathrm{CV}(\%)$ \\
\hline Vitamin $B_{7}$ (biotin) & $33.00 \pm 1.19$ & 3.6 & $32.79 \pm 1.63$ & 4.9 \\
\hline Vitamin $\mathrm{B}_{12}$ (cyanocobalmin) & $5.73 \pm 0.22$ & 3.8 & $5.60 \pm 0.34$ & 6.1 \\
\hline
\end{tabular}

${ }^{1)}$ Repeatability refers to the results of independent 5 determination in triplicates obtained by analyzing a QC sample five times on the same day. ${ }^{2}$ Reproducibility refers to the results of independent 5 determinations in triplicates obtained by analyzing a QC sample five times on different days (once a day).

${ }^{3)}$ Mean indicates the mean contents of biotin and cyanocobalamin in analytical quality sample, SD: standard deviation.

${ }^{4)}$ Coefficient variation. 
bility) 두 가지로 수행하였다(Table 3). 비오틴 분석에 대한 반 복성과 재현성은 각각 $3.6 \%, 4.9 \%$ 의 변동계수를 나타냈다. 코발라민류의 반복성은 $5.73 \mu \mathrm{g} / 100 \mathrm{~g}$, 재현성은 $5.60 \mu$ $\mathrm{g} / 100 \mathrm{~g}$ 으로 각각의 변동계수는 $3.8 \%, 6.1 \%$ 를 나타냈다. $\mathrm{AOAC}$ 가이드라인에서 제시하는 정밀성 범위는 $8 \%, 16 \%$ 이하를 제시하고 있으며 $(1 \mu \mathrm{g} / 100 \mathrm{~g})$, 분석값 모두 수용범위 이하의 값을 나타내 우수한 정밀성을 확인하였다.

\section{분석품질관리}

비오틴과 코발라민류의 분석품질관리는 QC chart를 이용 하여 수행하였으며 그 결과는 Fig. 2와 같다. 비오틴 분석 $\mathrm{QC}$ chart의 초기 설정한 평균값은 $32.89 \mu \mathrm{g} / 100 \mathrm{~g}$ 이었으며, 관리 상 - 하한선은 각각 $35.59 \mu \mathrm{g} / 100 \mathrm{~g}$ 과 $30.20 \mu \mathrm{g} / 100 \mathrm{~g}$, 조치 상 · 하한선은 각각 $36.93 \mu \mathrm{g} / 100 \mathrm{~g}$ 과 $28.85 \mu \mathrm{g} / 100 \mathrm{~g}$ 이 었다. 품질관리시료를 분석한 결과, 비오틴의 경우 1 회를 제 외한 모든 분석값이 관리한계선 범위 내에 들어감이 확인되 었으며 관리한계선 범위 밖의 분석값을 얻은 경우 검체 분석 을 중단하고, 분석 환경 및 조건을 검토한 이후 품질관리 시 료의 재분석 값이 관리한계선 범위 안으로 들어가게 되면 검
체 분석을 다시 진행하였으며, 이렇게 관리된 상태에서 분석 된 시료 분석값만을 채택하여 결과로 사용하였다. 코발라민 류 QC chart의 평균값은 $5.664 \mu \mathrm{g} / 100 \mathrm{~g}$ 을 나타냈으며, 관리 상-하한선은 $6.221 \mu \mathrm{g} / 100 \mathrm{~g}, 5.107 \mu \mathrm{g} / 100 \mathrm{~g}$ 으로, 조치 상 - 하한선 $6.499 \mu \mathrm{g} / 100 \mathrm{~g}, 4.828 \mu \mathrm{g} / 100 \mathrm{~g}$ 으로 나타났다. 코발라민류의 내부품질관리는 모든 분석 값이 관리 한계선 안에 들어가 분석이 수행되었음을 나타냈다.

\section{수산식품의 비오틴과 코발라민류 함량 분석}

수산자원 및 가공품의 비오틴 및 코발라민류 함량 분석 결 과는 Table 4와 같다. 총 28종의 수산물 및 수산가공품의 비 오틴과 코발라민류 함량범위는 각각 1.06-10.55 $\mu \mathrm{g} / 100 \mathrm{~g}$ 과 0.36-36.13 $\mu \mathrm{g} / 100 \mathrm{~g}$ 의 범위를 나타내어 코발라민류가 수산 자원의 종류에 따라 보다 넓은 함량 분포를 나타내는 것을 확인할 수 있었다. 수산자원 및 가공품 모두에서 비오틴 함량 이 검출되었으며, 이들의 함량을 비교해 보면 갑각류의 꽃게 (Gazami crab)에서 $10.55 \mu \mathrm{g} / 100 \mathrm{~g}$ 으로 함량이 가장 높았으며 다음으로 갑각류의 갯가재(Japanese squillid mantis shrimp) $5.40 \mu \mathrm{g} / 100 \mathrm{~g}$ 과 어류의 덕대(Korean pomfret) $5.07 \mu \mathrm{g} / 100$ 를

(A)
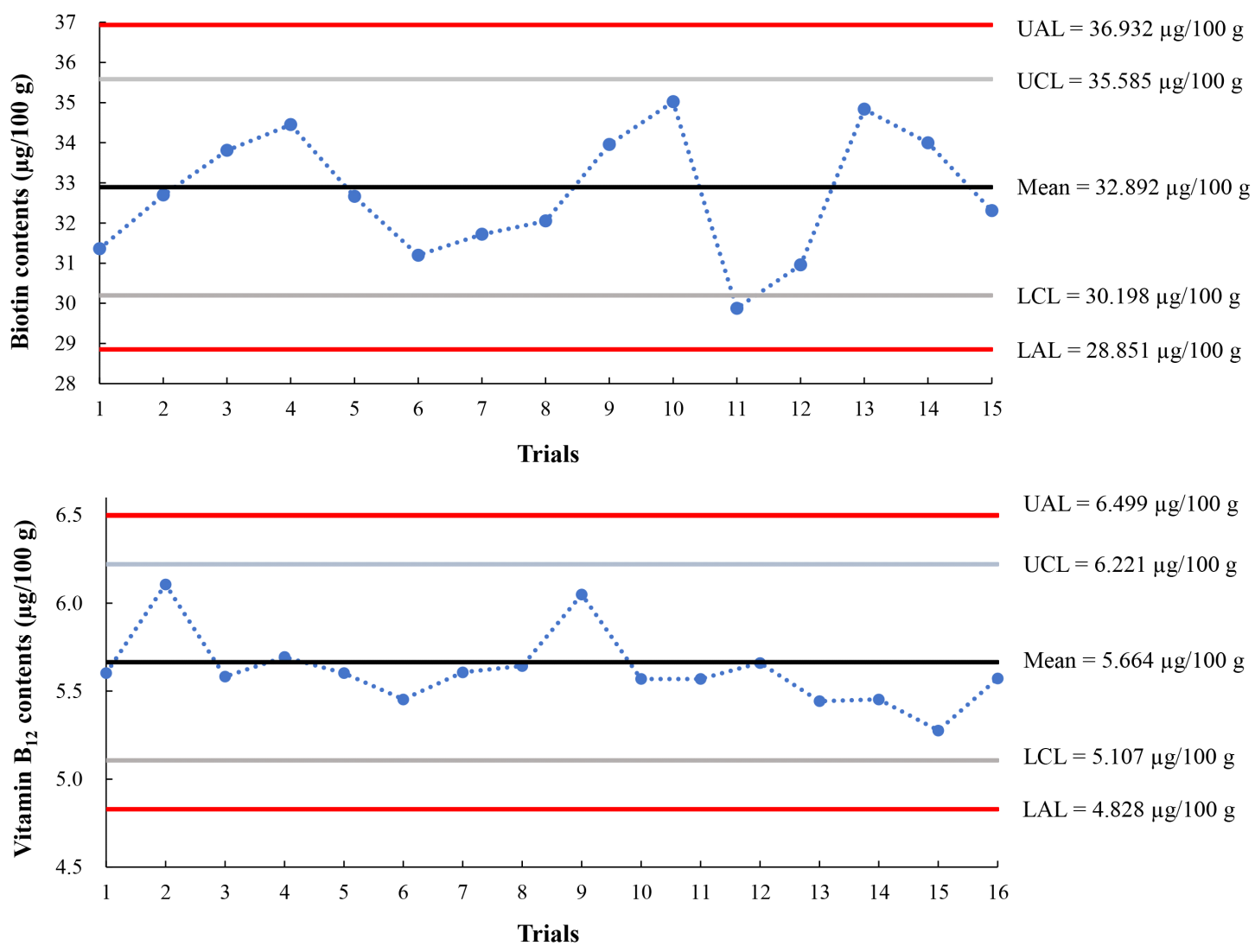

Fig. 2. Quality control charts of vitamin $B_{7}$ and $B_{12}$ analyses.

Upper and lower control lines (UCL and $\mathrm{LCL})=$ mean $\pm 2 \times \mathrm{SD}$, upper and lower action lines $(\mathrm{UAL}$ and $\mathrm{LAL})=\operatorname{mean} \pm 3 \times \mathrm{SD}$. 
Table 4. The contents of vitamin $B_{7}$ and $B_{12}$ in marine resources and products

\begin{tabular}{|c|c|c|c|c|}
\hline Classification & Samples & Scientific name & $\begin{array}{l}\text { Vitamin } B_{7} \\
(\mu \mathrm{g} / 100 \mathrm{~g})\end{array}$ & $\begin{array}{c}\text { Vitamin } \\
(\mu \mathrm{g} / 100 \mathrm{~g})\end{array}$ \\
\hline \multirow{4}{*}{$\begin{array}{l}\text { Fish } \\
(n=4)\end{array}$} & Blackthroat seaperch & Doederleinia berycoides & $1.37 \pm 0.12^{1)}$ & $1.40 \pm 0.09$ \\
\hline & Korean pomfret & Pampus argenteus & $5.07 \pm 0.07$ & $1.45 \pm 0.10$ \\
\hline & Pacific bluefin tuna & Thunnus orientalis & $1.29 \pm 0.10$ & $5.82 \pm 0.34$ \\
\hline & Pacific herring & Clupea pallasii & $1.34 \pm 0.12$ & $11.88 \pm 0.18$ \\
\hline \multirow{3}{*}{$\begin{array}{l}\text { Crustacean } \\
\quad(n=3)\end{array}$} & Razor mud shrimp & Solenocera melantho & $1.72 \pm 0.06$ & $1.30 \pm 0.04$ \\
\hline & Japanese squillid mantis shrimp & Oratosquilla oratoria & $5.40 \pm 0.15$ & $9.24 \pm 0.43$ \\
\hline & Gazami crab & Portunus trituberculatus & $10.55 \pm 0.14$ & $13.29 \pm 0.29$ \\
\hline \multirow{3}{*}{$\begin{array}{l}\text { Marine algae } \\
(n=3)\end{array}$} & Gulfweed & Sargassum fulvellum & $1.55 \pm 0.03$ & $1.07 \pm 0.03$ \\
\hline & Fusiformis & Hizikia fusiforme & $1.24 \pm 0.07$ & $0.36 \pm 0.03$ \\
\hline & Seersucker & Costaria costata & $1.44 \pm 0.10$ & $0.99 \pm 0.08$ \\
\hline \multirow{3}{*}{$\begin{array}{c}\text { Cephalopod } \\
(\mathrm{n}=3)\end{array}$} & Common squid & Todarodes pacificus & $1.59 \pm 0.07$ & $4.14 \pm 0.23$ \\
\hline & Schoolmaster gonate squid & Berryteuthis magister & $1.92 \pm 0.08$ & $1.64 \pm 0.05$ \\
\hline & Common octopus & Octopus vulgaris & $1.61 \pm 0.03$ & $1.13 \pm 0.07$ \\
\hline \multirow{4}{*}{$\begin{array}{l}\text { Shellfish } \\
(n=4)\end{array}$} & Ark shell & Scapharca broughtonii & $2.03 \pm 0.09$ & $36.13 \pm 0.47$ \\
\hline & Blue mussel & Mytilus edulis & $2.25 \pm 0.07$ & $17.88 \pm 0.77$ \\
\hline & Mussel & Mytilus coruscus & $5.02 \pm 0.09$ & $21.66 \pm 2.02$ \\
\hline & Spiny top shell & Turbo cornutus & $1.27 \pm 0.05$ & $1.09 \pm 0.07$ \\
\hline \multirow{3}{*}{$\begin{array}{l}\text { Others } \\
(n=3)\end{array}$} & Black sea cucumber & Stichopus japonicus & $2.17 \pm 0.11$ & $4.74 \pm 0.31$ \\
\hline & Common sea squirt & Halocynthia roretzi & $2.03 \pm 0.09$ & $6.15 \pm 0.21$ \\
\hline & Warty sea squirt & Styela clava & $1.98 \pm 0.14$ & $1.82 \pm 0.10$ \\
\hline \multirow{8}{*}{$\begin{array}{c}\text { Processed } \\
\text { product } \\
(\mathrm{n}=8)\end{array}$} & Anchovy sauce & - & $3.25 \pm 0.13$ & $2.11 \pm 0.14$ \\
\hline & Dried codfish & - & $4.22 \pm 0.04$ & $0.61 \pm 0.01$ \\
\hline & Half-dried Herring & - & $2.07 \pm 0.14$ & $25.83 \pm 1.43$ \\
\hline & Salted mackerel & - & $1.92 \pm 0.12$ & $6.50 \pm 0.31$ \\
\hline & Salted oysters & - & $2.26 \pm 0.11$ & $9.28 \pm 0.15$ \\
\hline & Salted pollack roe & - & $4.89 \pm 0.28$ & $8.00 \pm 0.28$ \\
\hline & Seasoned eel & - & $1.06 \pm 0.05$ & $2.72 \pm 0.16$ \\
\hline & Sliced smoked salmon & - & $1.33 \pm 0.08$ & $2.58 \pm 0.22$ \\
\hline
\end{tabular}

${ }^{1)}$ Mean \pm SD.

제외하고는 모두 $5 \mu \mathrm{g} / 100 \mathrm{~g}$ 이하의 함량 수준을 나타내었다. 인간은 체내에서 비오틴을 합성할 수 없기 때문에 식품과 보 충제 등을 통해 섭취해야 하는데, 한국인의 비오틴 일일 권장 섭취량 $30 \mu \mathrm{g}(\mathrm{MHW}, \mathrm{KNS}, 2015)$ 은 다양한 자원으로 구성된 한국인의 일반적인 식단의 경우 비오틴 권장섭취량은 충분히
충족될 수 있는 것으로 알려져 있다. 수산자원은 대체로 비오 틴 함량이 낮은 식품이지만 식단 속에서 섭취하게 되는 섭취 량과 빈도수가 높아 비오틴 섭취량에 충분한 기여를 하는 것 으로 알려져 있다(Ball, 2005). Kwon 등(2019)의 연구에 따 르면 포도의 품종 및 재배지역에 따라 비오틴의 함량이 달라 
진다고 하였으며, $\operatorname{Frigg}(1984)$ 는 동물성 자원의 경우 섭취시 키는 사료의 비오틴 함량 및 섭취량에 따라 동물자원의 비오 틴 함량이 달라지는 것으로 보인다고 보고하였다. 본 연구에 서 분석한 수산물의 경우도 종에 의한 다른 분포도를 나타내 었는데, 이러한 특성 외에도 생산지, 계절, 사료 등 다양한 생 육 환경에 따라 비오틴 함량이 달라질 수 있을 것으로 사료된 다.

한편, 수산자원 및 가공품의 코발라민류 함량의 분포는 어 류 $1.40-11.88 \mu \mathrm{g} / 100 \mathrm{~g}$, 갑각류 $1.30-13.29 \mu \mathrm{g} / 100 \mathrm{~g}$, 해조류 0.36-1.07 $\mu \mathrm{g} / 100 \mathrm{~g}$, 두족류 1.13-4.14 $\mu \mathrm{g} / 100 \mathrm{~g}$, 패류 1.09$36.13 \mu \mathrm{g} / 100 \mathrm{~g}$, 기타 $1.82-4.15 \mu \mathrm{g} / 100 \mathrm{~g}$, 가공품 0.61-25.83 $\mu \mathrm{g} / 100 \mathrm{~g}$ 으로 7 개 군별로 다양한 범위를 나타냈다. 일반적으 로 코발라민류는 식물성 식품에는 존재하지 않고 동물성 자 원에 주로 분포하고 있는 것으로 알려져 있다(Kuhne 등, 1991). 하지만 식물성 식품 중 식용 해조류에서 코발라민류 가 존재한다고 보고되어 있는데(Watanabe 등, 2002), 본 연 구에서 한국 식단에서 이용되고 있는 해조류인 모자반(gulfweed), 톳(Hizikia fusiforme), 쇠미역(seersucker)을 분석한 결과, 동물성 수산자원에 비하여 상대적으로 낮으나 동물성 식품에만 존재하는 코발라민류를 함유하고 있는 것으로 나타 났다. 이는 식용 해조류 자원이 채식주의자들에게는 식물성 식품에서 섭취할 수 없는 코발라민류를 보충할 수 있는 좋은 급원 식품이 될 수 있을 것으로 판단된다. 가장 높은 코발라 민류 함량을 보인 시료는 피조개(ark shell)로 $36.13 \mu \mathrm{g} / 100$ $\mathrm{g}$ 을 나타냈으며, 이 외에도 돌담치(mussel) $21.66 \mu \mathrm{g} / 100 \mathrm{~g}$, 진주담치(blue mussel) $17.88 \mu \mathrm{g} / 100 \mathrm{~g}$ 의 수준을 보여 전체적 으로 패류에서 코발라민류 함량이 다른 군에 비하여 높은 것 으로 보여진다. 하지만 패류 중 참소라(spiny top shell)의 경 우는 코발라민류 함량이 $1.09 \mu \mathrm{g} / 100 \mathrm{~g}$ 수준으로 해조류의 모자반과 유사한 수준의 함량을 나타났다. Petrus 등(2009)의 보고에 따르면 비타민 $\mathrm{B}_{12}$ 는 장내 미생물에 의해 합성되어 축적된다고 하였으며, 두족류의 경우 비가식 부위인 내장을 제거하여 섭취하지만 패류의 경우 내장을 같이 섭취하는 경 우가 많아 가장 높은 시아노코발라민 함량을 나타낸 것으로 사료된다. Jeong 등(2019)의 보고에 따르면 수산물을 주 재료 로 사용한 국 및 찌개류가 식물성 재료를 사용한 국 및 찌개 류보다 높은 비타민 $\mathrm{B}_{12}$ 함량을 나타내었다고 하였으며, 특히 패류를 사용한 국 및 찌개에서 가장 높은 비타민 $\mathrm{B}_{12}$ 함량을 나타냈다. 이는 패류 섭취가 코발라민류 급원에 도움을 줄 수 있는 것으로 보이며, 평균 필요량인 $2.0 \mu \mathrm{g} /$ 일을 충분히 섭취 할 수 있을 것으로 사료된다. 한편, 어류에서 청어(pacific herring)는 $11.88 \mu \mathrm{g} / 100 \mathrm{~g}$, 갑각류에서는 꽃게(gazami crab) $13.29 \mu \mathrm{g} / 100 \mathrm{~g}$, 가공품에서는 청어로 만든 과메기(half-dried herring) $25.83 \mu \mathrm{g} / 100 \mathrm{~g}$ 이 높은 코발라민류 함량을 나타냈다.
지금까지 국내에서 발간된 표준수산물성분표(2018)에는 비오틴과 코발라민류 함량에 대한 정보가 수록되지 않았으 나, 본 연구의 국내 수산물 및 수산가공품에 대한 비오틴 및 코발라민류 함량 분석법 검증 및 이를 적용한 분석 데이터는 표준수산물성분표의 데이터베이스 확대 구축에 활용될 수 있을 것으로 보여진다. 본 연구는 수산자원의 비오틴 및 코 발라민류 최적 단일분석법을 적용한 연구로 향후 국내에서 이용되고 있는 수많은 수산자원에 대한 지속적인 데이터베 이스 구축을 위해서는 시간과 비용을 절감할 수 있으면서도 수산자원의 복잡한 matrix에 적용하여 신뢰성 있는 결과를 얻을 수 있는 분석법 개발 및 검증 연구도 필요할 것으로 보 인다.

\section{요 약}

본 연구에서는 국내 수산자원의 비오틴과 코발라민류 함 량을 분석하여 신뢰도 있는 표준수산물성분표 데이터베이스 를 구축하기 위해 분석법을 검증하고, 선별된 28종의 수산자 원의 분석 및 분석품질관리를 실시하였다. 비오틴과 코발라 민류 분석은 immunoaffinity-HPLC/PDA법을 사용하여 각각 비오틴과 시아노코발라민을 분석 정량하였다. 분석법의 검출 한계, 정량한계, 직선성, 정확성, 정밀성에 대한 수행특성을 분석한 결과, 국제 가이드라인에서 제시하는 모든 수용범위 에 적합한 것을 확인할 수 있었다. 분석에 사용한 샘플은 총 28 종의 수산물 및 수산가공품을 총 7 개의 분류군으로 나누어 분석한 결과, 비오틴은 어류 $1.29-5.07 \mu \mathrm{g} / 100 \mathrm{~g}$, 갑각류 $1.72-10.55 \mu \mathrm{g} / 100 \mathrm{~g}$, 해조류 1.24-1.55 $\mu \mathrm{g} / 100 \mathrm{~g}$, 두족류 $1.59-1.92 \mu \mathrm{g} / 100 \mathrm{~g}$, 패류 $1.27-5.02 \mu \mathrm{g} / 100 \mathrm{~g}$, 기타 1.98-2.17 $\mu \mathrm{g} / 100 \mathrm{~g}$, 가공품 $1.06-4.89 \mu \mathrm{g} / 100 \mathrm{~g}$ 의 함량 범위를 나타내 었으며, 꽃게 $(10.55 \mu \mathrm{g} / 100 \mathrm{~g})$ 에서 가장 높은 함량을 나타냈 다. 코발라민류 분석 결과, 어류 $1.40-11.88 \mu \mathrm{g} / 100 \mathrm{~g}$, 갑각류 1.30-13.30 $\mu \mathrm{g} / 100 \mathrm{~g}$, 해조류 0.36-1.07 $\mu \mathrm{g} / 100 \mathrm{~g}$, 두족류 $1.13-4.14 \mu \mathrm{g} / 100 \mathrm{~g}$, 패류 $1.09-36.13 \mu \mathrm{g} / 100 \mathrm{~g}$, 기타 1.82$6.15 \mu \mathrm{g} / 100 \mathrm{~g}$, 가공품 $0.61-25.83 \mu \mathrm{g} / 100 \mathrm{~g}$ 의 함량범위를 보 였으며, 피조개 $(36.13 \mu \mathrm{g} / 100 \mathrm{~g})$ 가 가장 높은 함량을 나타냈 다. 시료 분석기간 동안 분석품질은 QC chart로 관리하였으 며, 전 분석 기간동안 신뢰성 있는 분석이 진행되었음을 확인 하였다. 본 연구에서는 국내 다양한 수산자원에 적용할 수 있 는 비오틴과 코발라민류 분석법을 검증하고, 이를 28 종의 수 산물 및 수산가공품에 적용하여 비오틴과 코발라민류의 함량 에 대한 신뢰성이 확보된 데이터를 확보하였으며, 이는 국가 표준수산물성분표의 데이터베이스 구축의 자료로의 활용과 함께 향후 다양한 국내 수산자원의 비오틴과 코발라민류의 데이터베이스 구축에 기여할 수 있을 것으로 사료된다. 


\section{감사의 글}

이 논문은 2020년도 국립수산과학원 수산시험연구사업 (R2020053)의 지원으로 수행되었으며, 이에 감사드립니다.

\section{Conflict of interests}

All authors declare no potential conflict of interest.

\section{ORCID}

Ye-Eun Park https://orcid.org/0000-0003-3936-0452

Jiyeon Chun https://orcid.org/0000-0002-0093-0203

\section{References}

Andres E, Loukili NH, Noel E, Kaltenbach G, Abdelgheni MB, Perrin AE, Noblet-Dick M, Maloisel F, Schlienger JL, Birchle JF. Vitamin $\mathrm{B}_{12}$ (cobalamin) deficiency in elderly patients. Can Med Assoc J, 171, 251- 259 (2004)

AOAC. AOAC Guidelines for Single Laboratory Validation of Chemical Methods for Dietary Supplements and Baotanicals. Association of Official Analytical Chemists, Gaithersburg, MD, USA, 2, p 12-13, 22 (2002)

Ball GFM. Vitamins in Foods-Analysis, Bioavailability and Stability. Taylor \& Francis, London, UK, p 165-166 (2005)

Bellows L, Moore R. Water-Soluble Vitamins: B-Complex and Vitamin C. Colorado State University, Fort Collins, CO, USA, p 312 (2012)

Carmel R. Current concepts in cobalamin deficiency. Annu Rev Med, 51, 357-375 (2000)

Cheon WY. Method validation and analysis of biotin in food by immunoaffinity assay. MS Thesis, Kyungsung University, Korea, p 18 (2019)

National Institute of Fisheries Science (NIFS). Composition Table Marine Products in Korea. 8th ed, National Institute of Fisheries Science, Busan, Korea, p 1-394 (2018)

Frigg M. Available biotin content of various feed ingredients. Poult Sci, 63, 750-753 (1984)

Healton EB, Savage DG, Brust JCM, Garrett TJ, Lindenbaum J. Neurologic aspects of cobalamin deficiency. Medicine, 70, 229-245 (1991)
Holler U, Wachter F, Wehrli C, Fizet C. Quantification of biotin in feed, food, tablets, and premixes using HPLCMS/MS. J Chromatogr B, 831, 8-16 (2006)

Huh YY, Kang YP, Choi YS, Park JH, Kwon SW. Development of analytical method of biotin in complex drugs and dietary supplements using HPLC-UV. J Pharm Invest, 41, 25-30 (2011)

International Conference on Harmonisation (ICH), Validation of analytical procedures: text and methodology Q2 (R1). Complementary guideline on methodology dated 6 November 1996 incorporated in November 2005. International Conference on Harmonisation, Geneva, Switzerland, p 11-12 (2005)

Jeong BG, Mun GJ, Jung JY, Chun JY. ImmunoaffinityHPLC analysis for vitamin $\mathrm{B}_{12}$ of Korean Cattle-Hanwoo (Bos taurus coreanae). Food Anal Method, 11, 25972606 (2018)

Jeong YN, Moon HG, Chun JY. Verification of folate and vitamin $\mathrm{B}_{12}$ analyses for Korean key soups and stews prepared according to standard Korean recipes. J Korean Soc Food Sci Nutr, 48, 1262-1271 (2019)

Joseph G, Devi R, Marley EC, Leeman D. Determination of biotin by liquid chromatography coupled with immunoaffinity column cleanup extraction: Single-laboratory validation, first action 2016. 02. J AOAC Int, 99, 1110-1112 (2016)

Kim JY, Kim SH, Lee YJ. Study of stability in the riboflavin content of dietary supplements on storage conditions. J Food Hyg Saf, 20, 225-231 (2005)

Kuhne T, Bubl R, Baumgartner R. Maternal vegan diet causing a serious infantile neurological disorder due to vitamin $\mathrm{B}_{12}$ deficiency. Eur J Pediatr, 150, 205-208 (1991)

Kwak CS, Park JH, Cho JH. Vitamin $\mathrm{B}_{12}$ content analysis of favorite Korean restaurant foods, convenient foods and bakery products. Korean J Nutr, 45, 588-599 (2012)

Kwon JH, Lee SH, Choi YM, Kim YH. Biotin analysis in selected agricultural foods consumed in Korea. J Korean Soc Food Sci Nurt, 48, 1366-1372 (2019)

Lahely S, Ndaw S, Arella F, Hasselmann C. Determination of biotin in foods by high-performance liquid chromatography with post-column derivatization and fluorimetric detection. Food Chem, 65, 253-258 (1999)

Lee GI, Kim SY. Analysis of the consumption structure of 
fishery products. J Rural Develop, 26, 21-38 (2003)

Martens JH, Barg H, Warren M, Jahn D. Microbial production of vitamin $\mathrm{B}_{12}$. Appl Microbiol Biotechnol, 58, 275-285 (2002)

Mun GJ, Song WJ, Park SH, Jeong BG, Jung GR, Choi KS, Kim JH, Choi YG, Chun JY, Kim JH, Choi YG, Chun $J Y$. Analysis of vitamin $B_{12}$ in fresh cuts of Korean pork for update of national standard food composition table. Korean J Food Preserv, 24, 983-991 (2017)

Norway Seafood Commision. Korea-Norway Seafood Symposium, Seoul, Korea (2017)

Pacheco-Alvarez D, Solorzano-Vargas RS, Rio ALD. Biotin in metabolism and its relationship to human disease. Arch Med Res, 33, 439-447 (2002)

Petrus AK, Fairchild TJ, Doyle RP. Traveling the vitamin $\mathrm{B}_{12}$ pathway: Oral delivery of protein and peptide drugs. Angew Chem Int Ed, 48, 1022-1028 (2009)

Said HM, Sharifian A, Bagherzadeh A, Mock D. Chronic ethanol feeding and acute ethanol exposure in vitro:
Effect on intestinal transport of biotin. Am J Clin Nutr, 52, 1083-1086 (1990)

Senyuva HZ, Gilbert J. Immunoffinity column clean-up techniques in food analysis: A review. J Chromatogr B, 878, 115-132 (2010)

Shin YW, Lee HJ, Ham HS, Shin SC, Kang YJ, Hwang KM, Kwon YK, Seo IW, Oh JM, Koo YE. Establishment of biotin analysis by LC- MS/MS method in infant milk formulas. J Food Hyg Saf, 31, 327-334 (2016)

Stabler SP. Vitamin $\mathrm{B}_{12}$ deficiency. N Engl J Med, 368, 149-160 (2013)

Swain R. An update of vitamin $\mathrm{B}_{12}$ metabolism and deficiency states. J Fam Pract, 41, 595-600 (1995)

Watanabe F, Takenaka S, Kittaka-Katsura H, Ebara S, Miyamoto E. Characterization and bioavailability of vitamin $\mathrm{B}_{12}$-compounds from edible algae. J Nutr Sci Vitaminol, 48, 325-331 (2002)

Zempleni J, Mock DM. Biotin biochemistry and human requirements. J Nutr Biochem, 10, 128-138 (1999) 